\title{
PENGARUH PERTUMBUHAN PENJUALAN, UKURAN PERUSAHAAN, DAN LEVERAGE TERHADAP PROFITABILITAS PADA PERUSAHAAN FOOD AND BEVERAGE BEI
}

\author{
I Ketut Alit Sukadana ${ }^{1}$ \\ Nyoman Triaryati ${ }^{2}$ \\ ${ }^{1,2}$ Fakultas Ekonomi dan Bisnis Universitas Udayana (Unud), Bali, Indonesia \\ e-mail: sukadana.alit@yahoo.com
}

\begin{abstract}
ABSTRAK
Profit atau laba perusahaan diperlukan untuk kepentingan hidup perusahaan untuk memperoleh profit. Tujuan penelitian ini adalah untuk mengetahui pengaruh pertumbuhan penjualan, leverage, dan ukuran perusahaan terhadap profitabilitas. Penelitian ini dilakukan pada Perusahaan Food and Beverage di Bursa Efek Indonesia periode 2012-2016. Jumlah populasi sebanyak 16 perusahaan, sample pada penelitian ini sebanyak 11 perusahaan dengan metode purposive sampling. Pengumpulan data dilakukan melalui data sekunder. Teknik analisis yang dilakukan pada penelitian ini menggunakan metode regresi linier berganda dengan menggunakan variabel bebas pertumbuhan penjualan, leverage, dan ukuran perusahaan. Berdasarkan hasil analisis ditemukan bahwa variabel pertumbuhan penjualan, leverage, dan ukuran perusahaan secara simultan berpengaruh signifikan terhadap profitabilitas. Hal ini menunjukkan semakin meningkatnya nilai pertumbuhan penjualan dan ukuran perusahaan dan menurunnya nilai leverage maka profitabilitas akan semakin meningkat. Pertumbuhan penjualan secara parsial berpengaruh positif signifikan terhadap profitabilitas. Leverage secara parsial berpengaruh negatif signifikan terhadap profitabilitas. Ukuran perusahaan secara parsial berpengaruh positif tidak signifikan terhadap profitabilitas.
\end{abstract}

Kata kunci : pertumbuhan penjualan, leverage, ukuran perusahaan, dan profitabilitas

\begin{abstract}
The purpose of this study is to determine the effect of sales growth, leverage, and company size on profitability. This research was conducted at Food and Beverage Company in Indonesia Stock Exchange period 2012-2016. Number of population as many as 16 companies, sample in this research 11 companies with purposive sampling method. Analytical techniques conducted in this study using multiple linear regression method using independent variables of sales growth, leverage, and company size. Based on the results of the analysis found that the variable of sales growth, leverage, and company size simultaneously have a significant effect on profitability. This shows the increasing value of sales growth and size of the company and the declining value of leverage then profitability will increase. Partial sales growth has a significant positive effect on profitability. Partial leverage has a significant negative effect on profitability. The size of the company partially positively insignificant to profitability.
\end{abstract}

Keywords: sales growth, leverage, firm size, and profitability 
I Ketut Alit Sukadana, Pengaruh Pertumbuhan...

\section{PENDAHULUAN}

Perusahaan sebagai salah satu bentuk organisasi pada umumnya memiliki tujuan tertentu yang ingin dicapai untuk memenuhi kepentingan para stakeholder. Tujuan dari sebuah perusahaan adalah untuk memaksimalkan nilai perusahaan dan menjaga kelangsungan kehidupan perusahaan. Salah satu usaha pencapaian tujuan perusahaan adalah dengan mendapatkan profit (keuntungan). Profit atau keuntungan perusahaan diperlukan untuk kepentingan hidup perusahaan untuk memperoleh profit tersebut perusahaan harus melakukan kegiatan operasional (Sunarto dan Budi, 2009). Menurut Nafarin (2007:788) profit adalah perbedaan antara pendapatan dengan keseimbangan biaya-biaya dan pengeluaran periode tertentu. Dapat disimpulkan profit merupakan suatu kelebihan pendapatan yang layak diterima oleh perusahaan yang bersangkutan setelah melakukan pengorbanan untuk pihak lain.

Profitabilitas adalah kemampuan perusahaan memperoleh profit dalam hubungannya dengan penjualan, total aktiva maupun modal sendiri (Sartono, 2010:122). Pada umumnya masalah profitabilitas lebih penting bagi perusahaan dibandingkan dengan masalah profit, karena besarnya profit yang diperoleh belum menggambarkan apakah perusahaan telah bekerja dengan efisien. Efisiensi baru dapat diketahui dengan membandingkan profit dengan kekayaan atau modal yang digunakan, dengan kata lain menghitung profitabilitasnya (Riyanto, 2011:37).

Profitabilitas suatu perusahaan menunjukkan perbandingan antara profit dengan aktiva atau modal yang menghasilkan profit tersebut, dengan kata lain 
profitabilitas adalah kemampuan perusahaan untuk menghasilkan profit selama periode tertentu (Riyanto, 2011:35). Tingkat profitabilitas menggambarkan kinerja perusahaan yang dilihat dari kemampuan perusahaan menghasilkan profit. Kemampuan perusahaan memperoleh profit ini menunjukkan apakah perusahaan mempunyai prospek yang baik atau tidak dimasa yang akan datang.

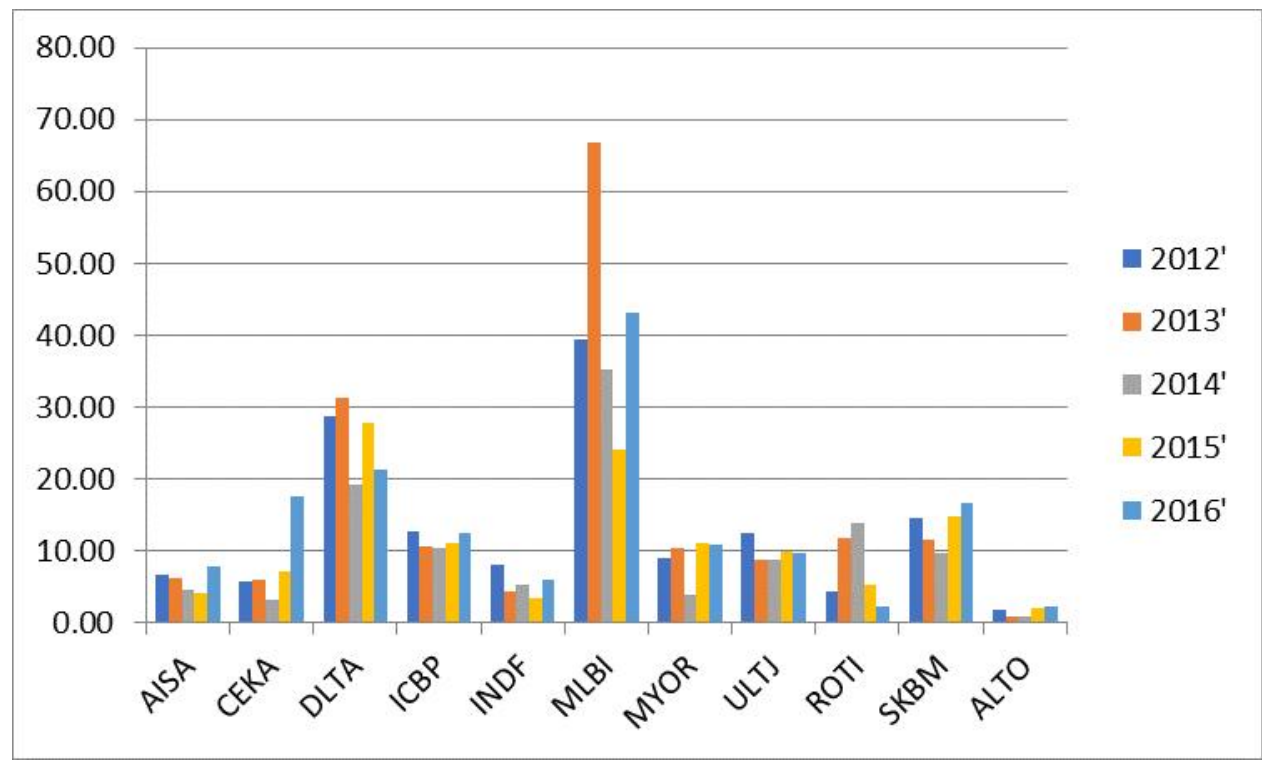

Grafik 1. Pertumbuhan Profitabilitas Sektor Food and Beverage di BEI Tahun 2012 - 2016

Sumber: data diolah, 2017

Penelitian ini menggunakan profitabilitas sebagai variabel independen, karena dapat dilihat pada Grafik 1 bahwa rata-rata profitabilitas pada sektor Food and Beverages di Bursa Efek Indonesia dengan periode 2012 - 2016 terdapat perbedaan yang signifikan pada setiap perusahaan. Grafik menunjukkan bahwa pertumbuhan profitabilitas sektor food and beverages di BEI mengalami fluktuasi pada tahun 2012 hingga 2016. Meskipun mengalami perbedaan pertumbuhan profitabilitas yang cukup signifikan setiap tahunnya, namun Sektor Food and Beverages masih tetap bertahan. Kementerian Perindustrian Republik Indonesia 
I Ketut Alit Sukadana, Pengaruh Pertumbuhan...

menyatakan bahwa industri Food and Beverages nasional terus menunjukkan kinerja positif dengan tumbuh mencapai 9,82 persen atau sebesar Rp192,69 triliun pada triwulan III 2016. Pertumbuhan industri ini terutama didorong kecenderungan masyarakat khususnya kelas menengah ke atas yang mengutamakan konsumsi produk-produk makanan dan minuman yang higienis dan alami. Industri makanan dan minuman juga mempunyai peranan penting dalam pembangunan sektor industri. Kontribusinya terhadap Produk Domestik Bruto (PDB) industri non migas merupakan yang terbesar dibandingkan subsektor lainnya yang mencapai 33,6 persen pada triwulan III tahun 2016. Kementerian Perindustrian Republik Indonesia juga memprediksi bahwa sektor makanan dan minuman tahun 2017 ini tumbuh kisaran 7,5 persen sampai 7,8 persen. Sementara, pengusaha memperkirakan bisa tumbuh minimal sama dengan 2016 yakni sekitar 8,2 persen hingga 8,5 persen (Kementerian Perindustrian Republik Indonesia, 2016).

Profitabilitas mempunyai arti penting bagi perusahaan karena merupakan salah satu dasar untuk penilaian kondisi suatu perusahaan. Tingkat profitabilitas menggambarkan kinerja perusahaan yang dilihat dari kemampuan perusahaan menghasilkan profit. Kemampuan perusahaan memperoleh profit ini menunjukkan apakah perusahaan mempunyai prospek yang baik atau tidak dimasa yang akan datang (Putra dan Badjra, 2015). Berdasarkan penelitian terdahulu profitabilitas dapat dipengaruhi oleh pertumbuhan penjualan, leverage, dan ukuran perusahaan. Penelitian yang dilakukan oleh Putra dan Badjra (2015) memperoleh hasil bahwa leverage berpengaruh negatif dan signifikan terhadap 
profitabilitas, pertumbuhan penjualan berpengaruh negatif dan tidak signifikan terhadap profitabilitas dan Ukuran perusahaan berpengaruh negatif dan tidak signifikan terhadap profitabilitas. Berbeda dengan penelitian Ratnasari dan Budiyanto (2016) yang menemukan hasil bahwa Leverage berpengaruh signifikan dan negatif terhadap profitabilitas, dan ukuran perusahaan berpengaruh tidak signifikan terhadap profitabilitas. Sedangkan penelitian yang dilakukan oleh Putri (2015) memperoleh hasil bahwa Likuiditas dan leverage berpengaruh terhadap profitabilitas, sedangkan pertumbuhan penjualan dan perputaran modal kerja tidak berpengaruh terhadap profitabilitas perusahaan. Oleh karena masih terdapat beberapa perbedaan hasil penelitian sebelumnya, maka yang menjadi variabel bebas pada penelitian ini adalah pertumbuhan penjualan, leverage, dan ukuran perusahan.

Penjualan merupakan salah satu sumber pendapatan perusahaan. Perusahaan pastinya menginginkan pertumbuhan penjualannya tetap stabil atau bahkan meningkat dari tahun ke tahun. Pertumbuhan penjualan adalah kenaikan jumlah penjualan dari tahun ke tahun atau dari waktu ke waktu (Kennedy dkk., 2013). Semakin tingginya penjualan bersih yang dilakukan oleh perusahaan dapat mendorong semakin tingginya profit kotor yang mampu diperoleh, sehingga dapat mendorong semakin tingginya profitabilitas perusahaan (Farhana dkk., 2016).

Pertumbuhan penjualan memiliki pengaruh yang strategis bagi perusahaan karena pertumbuhan penjualan ditandai dengan peningkatan market share yang akan berdampak pada peningkatan penjualan dari perusahaan sehingga akan meningkatkan profitabilitas dari perusahaan (Pagano dan Schivardi, 2003). Jika 
I Ketut Alit Sukadana, Pengaruh Pertumbuhan...

pertumbuhan penjualan perusahaan tetap stabil atau bahkan meningkat, dan biayabiaya dapat dikendalikan, maka profit yang diperoleh akan meningkat. Jika profit meningkat, maka profit yang akan diperoleh investor juga dapat meningkat.

Penelitian yang dilakukan oleh Hastuti (2010) yang menyatakan bahwa pertumbuhan penjualan berpengaruh positif dan signifikan terhadap profitabilitas. Pendapat yang sama dikemukakan oleh Jang dan Park (2011), Hansen dan Juniarti (2014) serta Iqbal dan Zhuquan (2015) yang menyatakan bahwa pertumbuhan penjualan berpengaruh positif dan signifikan terhadap profitabilitas. Penelitian berbeda dikemukakan oleh Santoso dan Juniarti (2014) dan Sari dkk. (2014) yang menemukan hasil bahwa pertumbuhan penjualan berpengaruh negatif terhadap profitabilitas perusahaan.

Leverage digunakan untuk mengukur sampai seberapa besar perusahaan dibiayai oleh modal pinjaman. Leverage adalah penggunaan aset dan sumber dana (sources of funds) oleh perusahaan yang memiliki biaya tetap (beban tetap) dengan maksud agar meningkatkan profit potensial pemegang saham (Sartono, 2010:123). Penggunaan hutang dalam kegiatan pendanaan perusahaan tidak hanya memberikan dampak yang baik bagi perusahaan. Jika proporsi leverage tidak dikelola dengan baik perusahaan, hal tersebut akan menyebabkan turunnya profitabilitas karena penggunaan hutang menimbulkan beban bunga yang bersifat tetap. Semakin tingginya jumlah hutang yang digunakan untuk membeli aset akan menyebabkan semakin tingginya bunga pinjaman yang akan ditanggung oleh perusahaan, sehingga akan menjadi permasalahan pada semakin rendahnya jumlah profit yang mampu diperoleh (Brigham dan Houston, 2010:189). 
Penelitian yang dilakukan oleh Rosyadah dkk. (2011) yang menemukan hasil bahwa DER berpengaruh negatif signifikan terhadap profitabilitas. Hasil serupa ditemukan oleh Mahardika dan Marbun (2016), dan Syarib (2016) yang menemukan hasil bahwa DER berpengaruh negatif signifikan terhadap profitabilitas. Penelitian berbeda dikemukakan oleh Wahyuni (2012) dan Nurhasanah (2012) menemukan bahwa DER berpengaruh positif terhadap profitabilitas perusahaan.

Ukuran perusahaan menggambarkan besar kecilnya suatu perusahaan (Sartono, 2010:249). Perusahaan yang relatif besar cenderung akan menggunakan dana eksternal yang besar pula karena dana yang dibutuhkan semakin meningkat seiring dengan pertumbuhan perusahaan (Ba-Abbad dan Zaluki, 2012). Munawir (2010:19) menyebutkan bahwa perusahaan-perusahaan yang memiliki ukuran perusahaan lebih besar memiliki dorongan yang kuat untuk menghasilkan tingkat profitabilitas yang tinggi dibandingkan dengan perusahaan-perusahaan yang lebih kecil.

Penelitian yang dilakukan oleh Ratnasari (2016) menunjukkan hasil bahwa ukuran perusahaan berpengaruh positif dan signifikan terhadap profitabilitas. Hasil serupa ditenukan oleh Velnampy dan Nimalathasan (2010), Nurmadi (2013) dan Babalola (2013) yang menyatakan bahwa ukuran perusahaan berpengaruh positif dan signifikan terhadap profitabilitas. Penelitian berbeda dikemukakan oleh Sari dan Budiasih (2014) menemukan bahwa ukuran perusahaan berpengaruh negatif terhadap profitabilitas perusahaan. 
Sektor Food and Beverage dipilih karena sektor ini merupakan salah satu sektor yang dapat bertahan di tengah kondisi perekonomian Indonesia, pertumbuhan penjualan cenderung berfluktuasi dari tahun 2012-2016. Hal ini disebabkan oleh karena sektor ini memproduksi produk makanan dan minuman yang merupakan salah satu kebutuhan penting bagi masyarakat Indonesia, meskipun dalam kondisi kritis sekalipun, perusahaan dalam sektor Food and Beverage masih tetap bertahan.

Berdasarkan perbedaan hasil penelitian terdahulu tentang faktor-faktor yang mempengaruhi profitabilitas perusahaan food and beverage, dan terdapatnya fluktuasi pada profitabilitas sektor food and beverage selama periode 2012-2016, maka penulis ingin mengetahui apakah leverage, ukuran perusahaan dan pertumbuhan penjualan berpengaruh terhadap profitabilitas pada perusahaan food and beverage di Bursa Efek Indonesia.

\section{Pengaruh Pertumbuhan Penjualan Terhadap Profitabilitas}

Pertumbuhan atas penjualan merupakan indikator penting dari penerimaan pasar dari produk dan atau jasa perusahaan tersebut, dimana pendapatan yang dihasilkan dari penjualan akan dapat digunakan untuk mengukur tingkat pertumbuhan penjualan (Swastha dan Handoko, 2001:125). Dengan mengetahui seberapa besar pertumbuhan penjualan, perusahaan dapat memprediksi seberapa besar profit yang akan didapatkan (Nugroho, 2011). Penjualan harus dapat menutupi biaya sehingga dapat meningkatkan profit (Brigham dan Houston, 2011: 168). Pertumbuhan penjualan memiliki pengaruh yang strategis bagi perusahaan karena pertumbuhan penjualan ditandai dengan peningkatan market share yang akan berdampak pada peningkatan penjualan dari perusahaan sehingga akan 
meningkatkan profitabilitas dari perusahaan (Putra dan Badjra, 2015). Penelitian empiris yang menguji pengaruh pertumbuhan penjualan terhadap profitabilitas diantaranya dilakukan oleh Hastuti (2010), Jang dan Park (2011), Hansen dan Juniarti (2014), Iqbal dan Zhuquan (2015), dan Suryaputra dan Christiawan (2016) yang memperoleh hasil dimana pertumbuhan penjualan berpengaruh positif dan signifikan terhadap profitabilitas. Berdasarkan uraian di atas, maka dapat disimpulkan:

$\mathrm{H}_{1}$ : Pertumbuhan penjualan berpengaruh positif dan signifikan terhadap profitabilitas

\section{Pengaruh Leverage terhadap Profitabilitas}

Perusahaan dengan pertumbuhan yang tinggi tentunya memerlukan dana yang tidak sedikit untuk membiayai aktivitas operasional perusahaannya. Kebutuhan dana tersebut dapat dipenuhi salah satunya dari sumber dana eksternal perusahaan, yaitu dengan hutang. Leverage adalah salah satu faktor penting yang memengaruhi profitabilitas karena leverage bisa digunakan perusahaan untuk meningkatkan modal perusahaan dalam rangka meningkatkan keuntungan (Singapurwoko, 2011). Leverage adalah penggunaan aset dan sumber dana (sources of funds) oleh perusahaan yang memiliki biaya tetap (beban tetap) dengan maksud agar meningkatkan keuntungan potensial pemegang saham (Sartono, 2010:123). Penggunaan hutang dalam kegiatan pendanaan perusahaan tidak hanya memberikan dampak yang baik bagi perusahaan. Jika proporsi leverage tidak diperhatikan perusahaan hal tersebut akan menyebabkan turunnya profitabilitas karena penggunaan hutang menimbulkan beban bunga yang bersifat tetap. Leverage dalam penelitian ini diproksikan dengan Debt to Equity Ratio 
(DER). Debt to Equity Ratio (DER) merupakan rasio yang membandingkan total hutang dengan total modal sendiri.

Peningkatan risiko leverage adalah kemungkinan terjadinya default karena perusahaan terlalu banyak melakukan pendanaan aktiva dari hutang. Perusahaan yang tidak sanggup membayar, maka biaya yang harus dikeluarkan oleh perusahaan untuk mengatasi masalah ini semakin besar (Mahardika dan Marbun, 2016). Rasio leverage (utang) menekankan pada peran penting pendanaan utang bagi perusahaan dengan menunjukkan persentase aktiva perusahaan yang didukung oleh pendanaan utang.

Leverage mempunyai pengaruh negatif terhadap profitabilitas perusahaan, karena tingkat leverage yang tinggi akan memiliki risiko yang tinggi dimana ditandai dengan adanya biaya hutang yang lebih besar. Hutang yang besar ini menyebabkan profitabilitas perusahaan yang bersangkutan rendah karena perhatian perusahaan dialihkan dari peningkatan produktivitas menjadi kebutuhan untuk menghasilkan arus kas untuk melunasi hutang mereka (Putra dan Badjra, 2015). Penelitian empiris yang menguji pengaruh leverage terhadap profitabilitas diantaranya dilakukan oleh Wahyuni (2012), Nurhasanah (2012), Dewi dkk. (2015), Rosyadah, dkk. (2013), dan Jatismara dan Pangestuti (2012) yang memperoleh hasil dimana leverage berpengaruh negatif dan signifikan terhadap profitabilitas. Berdasarkan uraian di atas, maka dapat disimpulkan:

$\mathrm{H}_{2}$ : Leverage berpengaruh negatif dan signifikan terhadap profitabilitas

Ukuran perusahaan digunakan untuk mengetahui adanya pengaruh naik dan turunnya profitabilitas. Profitabilitas dapat ditingkatkan apabila ukuran 
perusahaannya besar (Raheman dan Nasr, 2007). Kusuma (2005), menyebutkan bahwa menurut teori critical, semakin besar skala perusahaan maka profitabilitas juga akan meningkat, tetapi pada titik atau jumlah tertentu ukuran perusahaan akhirnya akan menurunkan profit (profit) perusahaan. Teori critical menekankan pada pengendalian oleh pemilik perusahaan terhadap sumber daya perusahaan seperti aset, teknologi, kekayaan intelektual sebagai faktor-faktor yang menentukan ukuran perusahaan.

Ukuran perusahaan mempengaruhi kemampuan perusahaan untuk memperoleh tambahan modal eksternal untuk membiayai aktivitas operasional perusahaan. Ukuran perusahaan menggambarkan besar kecilnya suatu perusahaan (Sartono, 2010:249). Perusahaan yang lebih besar akan semakin mudah untuk mendapatkan dana dalam jumlah yang besar sehingga akan membantu kegiatan operasional perusahaan dan menyebabkan produktivitas perusahaan meningkat sehingga profitabilitas perusahaan akan meningkat pula (Putra dan Badjra, 2015). Hal ini menjelaskan bahwa semakin besar ukuran perusahaan, maka semakin besar probabilitas untuk melakukan peningkatan laba. Ukuran perusahaan bisa dilihat dari total asset perusahaan, karena perusahaan dengan total asset yang besar mencerminkan kemapanan perusahaan (Ambarwati dkk., 2015).

Penelitian empiris yang menguji pengaruh ukuran perusahaan terhadap profitabilitas diantaranya dilakukan oleh Nurmadi (2013), Babalola (2013), Sari dan Budiasih (2014), Ambarwati (2015) dan Purba dan Yadnya (2015) yang memperoleh hasil dimana ukuran perusahaan berpengaruh positif dan signifikan terhadap profitabilitas. Berdasarkan uraian di atas, maka dapat disimpulkan: 
I Ketut Alit Sukadana, Pengaruh Pertumbuhan...

$\mathrm{H}_{3}$ : Ukuran perusahaan berpengaruh positif dan signifikan terhadap profitabilitas

Berdasarkan latar belakang dan kajian penelirian terdahulu yang telah diuraikan di atas, maka tujuan penelitian ini adalah untuk mengetahui signifikansi pengaruh pertumbuhan penjualan terhadap profitabilitas, untuk mengetahui signifikansi pengaruh leverage terhadap profitabilitas, dan untuk mengetahui signifikansi pengaruh ukuran perusahaan terhadap profitabilitas, sehingga dapat dibuat model kerangka konseptual seperti Gambar 1 berikut:

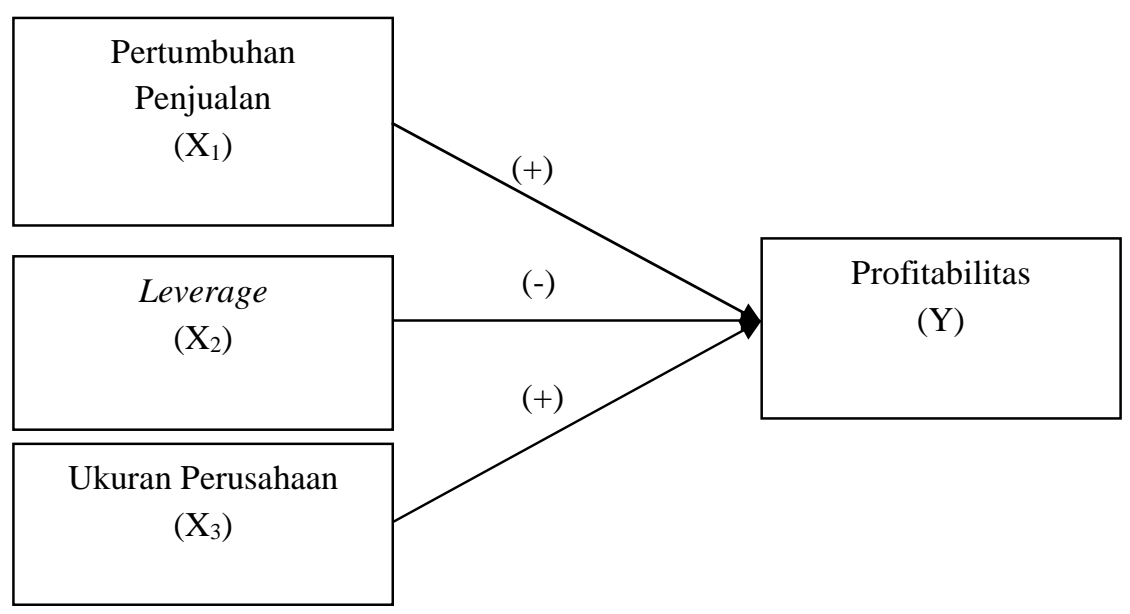

\section{Gambar 1. Model Kerangka Konseptual}

Sumber: Konsep yang dikembangkan dalam penelitian ini, 2017

\section{METODE PENELITIAN}

Berdasarkan permasalahan yang akan diteliti, penelitian ini digolongkan pada penelitian asosiatif (hubungan). Penelitian jenis ini hubungannya adalah hubungan linier karena bertujuan untuk mengetahui pengaruh variabel-variabel bebas $(\mathrm{X})$ terhadap variabel terikat $(\mathrm{Y})$. Variabel bebas yang digunakan yaitu pertumbuhan penjualan $\left(\mathrm{X}_{1}\right)$, leverage $\left(\mathrm{X}_{2}\right)$, dan ukuran perusahaan $\left(\mathrm{X}_{3}\right)$, sedangkan variabel terikatnya adalah profitabilitas (Y). 
Penelitian ini dilakukan pada perusahaan Sektor food and beverage di Bursa Efek Indonesia (BEI) dengan mengambil data dalam bentuk laporan keuangan tahunan dan laporan historis lainnya yang dipublikasikan BEI pada situs resmi www.idx.co.id pada periode 2012-2016. Obyek pada penelitian ini adalah profitabilitas pada perusahaan sektor food and beverage di Bursa Efek Indonesia periode 2012 - 2016.

Populasi dalam penelitian ini adalah perusahaan yang dikategorikan ke dalam sektor Food and Beverage di Bursa Efek Indonesia tahun 2012-2016. Perusahaan Sektor Food and Beverage yang terdaftar di Bursa Efek Indonesia dari tahun 2012 hingga 2016 adalah sebanyak 16 perusahaan. Pengambilan sampel dalam penelitian ini dilakukan dengan menggunakan metode purposive sampling yaitu teknik penentuan sampel secara tidak acak yang informasinya diperoleh dengan menggunakan pertimbangan tertentu. Beberapa kriteria pemilihan sampel Perusahaan yang digunakan adalah sebagai berikut:

\section{Tabel 1.}

Kriteria Penentuan Sampel

\begin{tabular}{lcc}
\hline \multicolumn{1}{c}{ Kriteria } & Jumlah \\
\hline $\begin{array}{l}\text { Perusahaan Sektor Food and Beverage yang listing di Bursa Efek Indonesia } \\
\text { periode 2012-2016 }\end{array}$ & 16 \\
$\begin{array}{l}\text { Perusahaan Sektor Food and Beverage yang delisting di Bursa Efek Indonesia } \\
\text { periode 2012-2016 }\end{array}$ & 4 \\
Jumlah Perusahaan Sektor Food and Beverage yang masih listing di Bursa Efek & 12 \\
$\begin{array}{l}\text { Indonesia periode 2012-2016 } \\
\text { Perusahaan Sektor Food and Beverage yang tidak memiliki data lengkap }\end{array}$ & 1 \\
Jumlah Perusahaan Sektor Food and Beverage yang memiliki data lengkap pada & 11 \\
periode 2012-2016 & \\
\hline
\end{tabular}

Sumber: data diolah, 2017

Berdasarkan hasil pengamatan dalam lima tahun pada periode 2012-2016, diperoleh 11 perusahaan Food and Beverage yang terdaftar di Bursa Efek Indonesia, seperti yang dijelaskan dalam Tabel 2 berikut : 
Tabel 2.

Daftar Sampel

\begin{tabular}{clc}
\hline No & \multicolumn{1}{c}{ Nama Perusahaan } & Kode Saham \\
\hline 1 & PT. Tiga Pilar Sejahtera Tbk & AISA \\
2 & PT. Wilmar Cahaya Indonesia Tbk & CEKA \\
3 & PT. Delta Djakarta Tbk & DLTA \\
4 & PT. Indofood CBP Sukses Makmur Tbk & ICBP \\
5 & PT. Indofood Sukses Makmur Tbk & INDF \\
6 & PT. Multi Bintang Indonesia Tbk & MLBI \\
7 & PT. Mayora Indah Tbk & MYOR \\
8 & PT. Ultrajaya Milk Industry \& Trading Co Tbk & ULTJ \\
9 & PT. Nippon Indosari Corpindo Tbk & ROTI \\
10 & PT. Sekar Bumi Tbk & SKBM \\
11 & PT. Tri Banyan Tirta Tbk & ALTO \\
\hline
\end{tabular}

Sumber: data diolah, 2017

Teknik analisis data yang digunakan dalam penelitian ini adalah analisis regresi linier berganda. Analisis regresi linier berganda digunakan untuk mengetahui pengaruh variabel bebas terhadap variabel terikat atas perubahan dari setiap peningkatan atau penurunan variabel yang akan mempengaruhi variabel terikat. Model regresi yang digunakan dalam penelitian ini adalah sebagai berikut:

$$
\mathrm{Y}=\alpha+\beta_{1} \mathrm{X}_{1}+\beta_{2} \mathrm{X}_{2}+\beta_{3} \mathrm{X}_{3}+\mathrm{e}
$$

Keterangan:

$$
\begin{aligned}
& \mathrm{Y}=\text { Profitabilitas } \\
& \mathrm{X}_{1}=\text { Pertumbuhan Penjualan } \\
& \mathrm{X}_{2}=\text { Leverage } \\
& \mathrm{X}_{3}=\text { Ukuran Perusahaan } \\
& \beta_{1}=\text { Koefisien regresi dari } \mathrm{X}_{1} \\
& \beta_{2}=\text { Koefisien regresi dari } \mathrm{X}_{2} \\
& \beta_{3}=\text { Koefisien regresi dari } \mathrm{X}_{3} \\
& \mathrm{e}=\text { error term }
\end{aligned}
$$

\section{HASIL DAN PEMBAHASAN}

Hasil analisis data deskriptif dalam penelitian ini dilakukan untuk memberikan gambaran atau deskripsi mengenai variabel yang diteliti dimana 
terdiri dari Pertumbuhan Penjualan $\left(\mathrm{X}_{1}\right)$, Ukuran Perusahaan $\left(\mathrm{X}_{2}\right)$, Leverage (DER) $\left(\mathrm{X}_{3}\right)$, dan Profitabilitas (ROA) $(\mathrm{Y})$ yang terlihat dari tabel 3 berikut:

Tabel 3.

Statistik Deskriptif Sampel Penelitian

\begin{tabular}{lcrrrr}
\hline & N & Minimum & Maximum & Mean & $\begin{array}{c}\text { Std. } \\
\text { Deviation }\end{array}$ \\
\hline ROA & 55 & .80 & 66.91 & 12.6727 & 12.15186 \\
Pertumbuhan Penjualan & 55 & .74 & 127.31 & 26.1545 & 21.54654 \\
Ln Size & 555 & 25.72 & 31.83 & 29.1534 & 1.63415 \\
DER & 5 & 18.32 & 177.05 & 93.4996 & 42.47242 \\
Valid N (listwise) & 55 & & & & \\
\hline Sumber: Data sekunder diolah, 2017 & & & & &
\end{tabular}

Tabel 3 menunjukkan bahwa jumlah data yang digunakan dalam penelitian ini berjumlah 55 sampel data. Data sampel ini menjelaskan nilai minimum, maksimum, rata-rata dan standar deviasi dari masing-masing variabel. Berdasarkan perhitungan selama periode pengamatan menunjukkan bahwa variabel Profitabilitas tertinggi dimiliki oleh PT. Multi Bintang Indonesia Tbk (MLBI) pada periode 2013 sebesar 0,80, artinya perbandingan profitabilitas MLBI periode 2013 dengan profitabilitas MLBI periode 2014 mengalami peningkatan sebesar 66,91 persen. Nilai Profitabilitas terendah dimiliki oleh PT. Tri Banyan Tirta Tbk (ALTO) pada tahun 2014 sebesar 0,80, artinya perbandingan profitabilitas ALTO periode 2014 dengan profitabilitas ALTO 2015 mengalami penurunan sebesar 0,80 persen. Bila dilihat secara rata-rata return saham selama tahun 2012 hingga 2016 yaitu sebesar 12,6727 persen dan standar deviasi yaitu sebesar 12,15186 .

Variabel pertumbuhan penjualan tertinggi ditemukan pada perusahaan PT. Multi Bintang Indonesia Tbk (MLBI) pada periode 2013 sebesar 127,31, artinya penjualan pada tahun 2013 mengalami peningkatan dibandingkan tahun 2012 
I Ketut Alit Sukadana, Pengaruh Pertumbuhan...

sebesar 127,31 persen. Nilai pertumbuhan penjualan terendah pada perusahaan PT. Indofood Sukses Makmur Tbk (INDF) pada periode 2015 sebesar 0,74, artinya penjualan pada tahun 2015 mengalami penurunan dibandingkan tahun 2014 sebesar 0,74 persen. Bila dilihat secara rata-rata pertumbuhan penjualan selama tahun 2012 hingga 2016 yaitu sebesar 26,1545 persen dan standar deviasi yaitu sebesar 21.54654 .

Variabel ukuran perusahaan tertinggi dimiliki oleh PT. Indofood Sukses Makmur Tbk (INDF) pada periode 2016 sebesar 31,83, artinya ukuran perusahaan yang dimiliki perusahaan adalah sebesar 31,83 persen. Nilai ukuran perusahaan terendah dimiliki oleh PT. Tri Banyan Tirta Tbk (ALTO) pada tahun 2012 sebesar 25,72, artinya ukuran peusahaan terendah pada perusahaan ALTO terdapat pada perode 2012 adalah sebesar 25,72 persen. Bila dilihat secara rata-rata ukuran perusahaan selama tahun 2012 hingga 2016 yaitu sebesar 29,1534 persen dan standar deviasi yaitu sebesar 1,63415.

Variabel DER tertinggi dimiliki oleh PT. Tri Banyan Tirta Tbk (ALTO) pada periode 2013 sebesar 177,05, artinya perbandingan antara total utang dengan ekuitas perusahaan sebesar 177,05 persen. Nilai DER terendah dimiliki oleh PT. Delta Djakarta Tbk (DLTA) pada tahun 2016 sebesar 18,32, artinya artinya perbandingan antara total utang dengan ekuitas perusahaan sebesar 18,32 persen. Bila dilihat secara rata-rata DER selama tahun 2013 hingga 2015 yaitu sebesar 93.4996 persen dan standar deviasi yaitu sebesar 42.47242 .

Analisis regresi linier berganda digunakan untuk arah dan besarnya pengaruh pertumbuhan penjualan, leverage dan ukuran perusahaan terhadap 
profitabilitas pada perusahaan Sektor Food and Beverage di Bursa Efek Indonesia periode 2012-2016 secara parsial. Hasil regresi linier berganda untuk penelitian ini dapat dilihat dalam Tabel 4 berikut.

Tabel 4.

Analisis Regresi Linier Berganda

\begin{tabular}{|c|c|c|c|c|c|c|}
\hline & \multirow[t]{2}{*}{ Model } & \multicolumn{2}{|c|}{$\begin{array}{c}\text { Unstandardized } \\
\text { Coefficients }\end{array}$} & \multirow{2}{*}{$\begin{array}{c}\begin{array}{c}\text { Standardized } \\
\text { Coefficients }\end{array} \\
\text { Beta }\end{array}$} & \multirow[t]{2}{*}{$\mathbf{T}$} & \multirow[t]{2}{*}{ Sig } \\
\hline & & B & $\begin{array}{l}\text { Std. } \\
\text { Error }\end{array}$ & & & \\
\hline \multirow[t]{4}{*}{1} & (Constant) & -4.564 & 20.777 & & -.220 & .827 \\
\hline & Pertumbuhan Penjualan & .329 & .056 & .584 & 5.883 & .000 \\
\hline & DER & -.089 & .020 & -.310 & -2.957 & .005 \\
\hline & Ln_Size & .580 & .657 & .078 & 0.883 & .381 \\
\hline
\end{tabular}

Berdasarkan analisis data yang telah ditampilkan pada Tabel 4 maka dapat dibuat persamaan regresi linear berganda sebagai berikut:

$$
Y=-4,562+0,329 X_{1}-0,089 X_{2}+0,580 X_{3}
$$

Persamaan regresi linear berganda tersebut menunjukkan arah masingmasing variabel bebas terhadap variabel terikatnya, dimana koefisien regresi variabel bebas yang bertanda positif berarti mempunyai pengaruh yang searah terhadap profitabilitas dan yang bertanda negatif berarti mempunyai pengaruh yang berlawanan terhadap profitabilitas.

Uji normalitas bertujuan untuk menguji apakah model regresi, variabelvariabel penelitian telah berdistribusi normal atau tidak. Model regresi yang baik memiliki data yang berdistribusi normal. Ada dua cara untuk mendeteksi apakah residual berdistribusi normal atau tidak yaitu dengan analisis grafik dan uji statistik (Ghozali, 2012:160). Uji normalitas pada penelitian ini menggunakan uji statistic non-parametrik Kolmogorov-Smirnov (K-S). apabila Asymp. Sig (2- 
tailed) $>\alpha(0,05)$ maka dikatakan data terdistribusi normal (Ghozali, 2012: 164). Hasil uji normalitas untuk penelitian ini dapat dilihat dalam Tabel 5 berikut.

Tabel 5. Uji Normalitas

\begin{tabular}{llr}
\hline & & Unstandardized Residual \\
\hline $\mathrm{N}$ & & 55 \\
Normal Parameters(a,b) & Sean & .0000000 \\
& & 7.13355517 \\
Most Extreme Differences & Absolute & .081 \\
& Positive & .065 \\
Kolmogorov-Smirnov Z & Negative & -.081 \\
Asymp. Sig. (2-tailed) & & .603 \\
\hline Sumber: Data sekunder diolah, 2017 & .861 \\
\hline
\end{tabular}

Pada tabel 5 diketahui bahwa nilai signifikansi sebesar 0,861 $(0,861>0,05)$, hal ini berarti model regresi berdistribusi normal dan memenuhi asumsi normalitas, sehingga dapat digunakan dalam analisis parametrik.

Uji autokorelasi merupakan korelasi atau hubungan yang terjadi diantara anggota-anggota dari serangkaian pengamatan yang tersusun dalam rangkaian deret waktu (time series) maupun tersusun dalam rangkaian ruang yang disebut cross sectional. Uji autokorelasi bertujuan untuk menguji apakah dalam suatu model regresi pada periode $\mathrm{t}$ dengan kesalahan pengganggu pada periode $\mathrm{t}-1$. Untuk mengetahui ada tidaknya besaran auto korelasi dapat digunakan besaran Durbin-Watson (D-W) pada output pengujian. Nilai (D-W) dengan menggunakan tingkat keyakinan sebesar 95 persen dengan ketentuan bila dU $<$ DW $<4-$ dU, maka tidak terjadi autokorelasi. Penelitian ini menggunakan $n($ jumlah data $)=55$ dan $\mathrm{k}$ (jumlah variabel $)=4$, maka diperoleh nilai $\mathrm{dU}=(1,7240)$ dan $4-\mathrm{dU}=$ (2,276). Hasil uji autokorelasi dengan menggunakan Durbin-Watson (D-W) test disajikan pada tabel 6 berikut ini. 
Tabel 6.

Hasil Uji Autokorelasi

\begin{tabular}{cccccc}
\hline Model & R & R Square & $\begin{array}{c}\text { Adjusted R } \\
\text { Square }\end{array}$ & $\begin{array}{c}\text { Std. Error of the } \\
\text { Estimate }\end{array}$ & $\begin{array}{c}\text { Durbin- } \\
\text { Watson }\end{array}$ \\
\hline $\mathbf{1}$ & $.810(\mathrm{a})$ & .655 & .635 & 7.34037 & 2.007 \\
\hline Sumber: Data sekunder diolah, 2017 & & & &
\end{tabular}

Berdasarkan Tabel 6 diperoleh nilai Durbin-Watson (D-W) sebesar 2,007.

Nilai tersebut berada diantara $\mathrm{dU}=1,7240$ dan $4-\mathrm{dU}=2,276$ atau $1,7240<$ 2,007 < 2,276 yang merupakan daerah bebas autokorelasi atau model regresi yang dibuat tidak mengandung gejala autokorelasi.

Uji multikolinearitas bertujuan untuk menguji apakah model regresi ditemukan adanya korelasi antara variabel bebas, apabila terjadi korelasi maka terdapat masalah multikolinearitas. Gejala ini dapat dideteksi dengan melihat nilai Tolerance Inflation Factor (VIF). Hasil uji multikolinearitas untuk penelitian ini dapat dilihat dalam Tabel 7 berikut.

Tabel 7.

Uji Multikolinearitas

\begin{tabular}{llcc}
\hline & \multicolumn{1}{c}{ Model } & \multicolumn{2}{c}{ Collinearity Statistics } \\
\cline { 3 - 4 } & & Tolerance & VIF \\
\hline 1 & Pertumbuhan Penjualan & .686 & 1.458 \\
& DER & .616 & 1.624 \\
& Ln_Size & .866 & 1.154 \\
\hline
\end{tabular}

Sumber: Data sekunder diolah, 2017

Berdasarkan Tabel 7 dapat dilihat nilai Tolerance untuk variabel pertumbuhan penjualan, leverage, dan ukuran perusahaan secara berturut-turut sebesar 0,686; 0,616; dan 0,866. Nilai VIF dari variabel pertumbuhan penjualan, leverage, dan ukuran perusahaan secara berturut-turut sebesar 1,458; 1,624; dan 1,154 sehingga dapat disimpulkan bahwa model regresi bebas dari multikolinearitas. 
I Ketut Alit Sukadana, Pengaruh Pertumbuhan...

Uji heterokedastisitas bertujuan untuk menguji apakah dalam model regresi terjadi ketidaksamaan variance dari residual satu pengamatan ke pengamatan yang lain, apabila variance dari residual satu pengamatan ke pengamatan lain tetap maka disebut homokedastisitas dan jika berbeda disebut heterokedastisitas. Model regresi yang baik adalah yang homokedastisitas atau tidak terjadi heterokedastisitas (Ghozali, 2012:139). Penelitian ini menggunakan uji Glejser, apabila probabilitas signifikansinya di atas tingkat kepercayaan 5 persen $(0,05)$. Maka dapat disimpulkan model regresi tidak mengandung adanya heterokedastisitas (Ghozali, 2012:143). Berikut ini disajikan hasil uji heterokedastisitas yang dapat dilihat pada Tabel 8 .

Tabel 8.

Uji Heterokedastisitas

\begin{tabular}{|c|c|c|c|c|c|c|}
\hline & \multirow[t]{2}{*}{ Model } & \multicolumn{2}{|c|}{$\begin{array}{l}\text { Unstandardized } \\
\text { Coefficients }\end{array}$} & \multirow{2}{*}{$\begin{array}{l}\text { Standardized } \\
\text { Coefficients } \\
\text { Beta }\end{array}$} & \multirow[t]{2}{*}{$\mathrm{T}$} & \multirow[t]{2}{*}{ Sig } \\
\hline & & B & Std. Error & & & \\
\hline \multirow[t]{4}{*}{1} & (Constant) & -7.634 & 10.331 & & -.739 & .463 \\
\hline & Pertumbuhan Penjualan & .147 & .028 & .667 & 5.269 & .431 \\
\hline & DER & .003 & .015 & .028 & .207 & .837 \\
\hline & Ln_Size & .302 & .327 & .104 & .924 & .360 \\
\hline
\end{tabular}

Sumber: Data sekunder diolah, 2017

Berdasarkan Tabel 8, ditunjukkan bahwa masing-masing model memiliki nilai signifikansi lebih besar dari 5 persen $(0,05)$ berturut-turut pertumbuhan penjualan, leverage, dan ukuran perusahaan yaitu 0,$431 ; 0,837$; dan 0,360 , maka dapat disimpulkan tidak terjadi heterokedastisitas.

Nilai Adjusted $\mathrm{R}^{2}$ dalam penelitian ini adalah sebesar 0,635 yang berarti variabel bebas dalam penelitian ini yaitu pertumbuhan penjualan, leverage, dan ukuran perusahaan dalam model regresi mampu menjelaskan variasi profitabilitas 
sebesar 63,5 persen, sedangkan 36,5 persennya dijelaskan oleh faktor-faktor lain diluar variabel bebas yang digunakan dalam penelitian ini.

Tabel 9.

Uji Koefisien Determinasi

\begin{tabular}{ccccc}
\hline Model & $\mathbf{R}$ & R Square & $\begin{array}{c}\text { Adjusted R } \\
\text { Square }\end{array}$ & $\begin{array}{c}\text { Std. Error of the } \\
\text { Estimate }\end{array}$ \\
\hline $\mathbf{1}$ & $.810(\mathrm{a})$ & .655 & .635 & 7.34037 \\
\hline
\end{tabular}

Sumber: Data sekunder diolah, 2017

Uji $\mathrm{F}$ bertujuan untuk mengukur kelayakan model regresi yang diestimasi layak atau tidak digunakan untuk menjelaskan pengaruh variabel bebas terhadap variabel terikat. Berikut ini disajikan hasil uji F yang dapat dilihat pada Tabel 4.7.

Tabel 10.

\begin{tabular}{llrrrrr}
\multicolumn{8}{c}{ Uji F } \\
\hline & Model & \multicolumn{1}{c}{ Sum of } & Df & \multicolumn{1}{c}{ Mean } & F & Sig. \\
& & Squares & & \multicolumn{1}{c}{ Square } & & \\
\hline $\mathbf{1}$ & Regression & 5226.123 & 3 & 1742.041 & 32.331 & $.000(\mathrm{a})$ \\
& Residual & 2747.931 & 51 & 53.881 & & \\
& Total & 7974.504 & 54 & & & \\
\hline
\end{tabular}

Sumber: Data sekunder diolah, 2017

Berdasarkan hasil uji $\mathrm{F}$ yang telah dilakukan, nilai signifikan $\mathrm{F}$ diketahui sebesar 0,000. Nilai signifikan tersebut lebih kecil dari taraf signifikansi 0,05, maka dapat disimpulkan bahwa secara serempak layak digunakan.

\section{Pengaruh pertumbuhan penjualan terhadap profitabilitas}

Hasil pengujian statistik pada pertumbuhan penjualan secara parsial menunjukkan adanya pengaruh positif dan signifikan terhadap profitabilitas. Temuan ini konsisten dengan hasil penelitian yang dilakukan oleh Iqbal dan Zhuquan (2015), dan Suryaputra dan Christiawan (2016) yang menyatakan pertumbuhan penjualan berpengaruh positif dan signifikan terhadap profitabilitas. 
I Ketut Alit Sukadana, Pengaruh Pertumbuhan...

Pertumbuhan penjualan merupakan perubahan penjualan pada laporan keuangan per tahun. Pertumbuhan penjualan yang di atas rata-rata bagi suatu perusahaan umumnya didasarkan pada pertumbuhan yang cepat yang diharapkan dari industri dimana perusahaan itu beroperasi Fabozzi (2000: 881). Dengan mengetahui seberapa besar pertumbuhan penjualan, perusahaan dapat memprediksi seberapa besar profit yang akan didapatkan (Nugroho, 2011). Semakin tingginya penjualan bersih yang dilakukan oleh perusahaan dapat mendorong semakin tingginya profit kotor yang mampu diperoleh, sehingga dapat mendorong semakin tingginya profitabilitas perusahaan (Farhana dkk., 2016).

\section{Pengaruh Leverage terhadap Profitabilitas}

Hasil pengujian statistik pada pertumbuhan penjualan secara parsial menunjukkan adanya pengaruh negatif dan signifikan terhadap profitabilitas. Temuan ini konsisten dengan hasil penelitian yang dilakukan oleh Rosyadah, dkk. (2013), dan Jatismara dan Pangestuti (2012) yang menyatakan leverage berpengaruh negatif dan signifikan terhadap profitabilitas. Leverage adalah penggunaan aset dan sumber dana (sources of funds) oleh perusahaan yang memiliki biaya tetap (beban tetap) dengan maksud agar meningkatkan keuntungan potensial pemegang saham (Sartono, 2010:123). Penggunaan hutang dalam kegiatan pendanaan perusahaan tidak hanya memberikan dampak yang baik bagi perusahaan. Jika proporsi leverage tidak diperhatikan perusahaan hal tersebut akan menyebabkan turunnya profitabilitas karena penggunaan hutang menimbulkan beban bunga yang bersifat tetap. (Putra dan Badjra, 2015). Hasil penelitian ini menunjukkan bahwa leverage berpengaruh negatif terhadap 
profitabilitas perusahaan, hal ini mengindikasikan bahwa tingkat leverage yang tinggi akan memiliki risiko yang tinggi dimana ditandai dengan adanya biaya hutang yang lebih besar. Hutang yang besar ini menyebabkan profitabilitas perusahaan yang bersangkutan rendah karena perhatian perusahaan dialihkan dari peningkatan produktivitas menjadi kebutuhan untuk menghasilkan arus kas untuk melunasi hutang mereka.

\section{Pengaruh Ukuran Perusahaan terhadap Profitabilitas}

Ukuran perusahaan digunakan untuk mengetahui adanya pengaruh naik dan turunnya terhadap profitabilitas. Profitabilitas dapat ditingkatkan apabila ukuran perusahaannya besar (Raheman dan Nasr, 2007). Berdasarkan analisis regresi linier berganda ditemukan bahwa variabel ukuran perusahaan berpengaruh positif dan tidak signifikan terhadap profitabilitas. Menurut Fachrudin (2011) ukuran perusahaan bukan jaminan bahwa perusahaan memiliki kemampuan dalam menghasilkan profit yang baik. Pengaruh yang tidak signifikan ini diakibatkan oleh semakin besar ukuran suatu perusahaan, maka perusahaan tersebut akan membutuhkan biaya yang semakin besar untuk menjalankan aktivitas operasionalnya seperti biaya tenaga kerja, biaya administrasi dan umum serta biaya pemeliharaan gedung, mesin, kendaraan dan peralatan sehingga akan mampu mengurangi profitabilitas perusahaan (Sari dan Budiasih, 2014). Hasil penelitian ini menunjukkan bahwa ukuran perusahaan tidak berpengaruh signifikan terhadap profitabilitas, hal ini disebabkan karena peningkatan penjualan pada perusahaan food and beverage periode 2012-2016 disertai peningkatan biaya yang lebih besar sehingga profit yang diharapkan tidak tercapai, disamping faktor 
I Ketut Alit Sukadana, Pengaruh Pertumbuhan...

lain diantara investasi untuk meningkatkan penjualan seperti penambahan aktiva yang dilakukan ternyata tidak menghasilkan keuntungan yang berarti hal ini disebabkan tidak adanya studi kelayakan atas investasi.

\section{Implikasi Hasil Penelitian}

Penelitian yang dilakukan diharapkan dapat memberikan kontribusi mengenai pengaruh pertumbuhan penjualan, ukuran perusahaan, dan leverage terhadap profitabilitas. Hasil uji hipotesis pertama dalam penelitian ini ditemukan bahwa pertumbuhan penjualan berpengaruh positif terhadap profitabilitas. Semakin tingginya penjualan bersih yang dilakukan oleh perusahaan dapat mendorong semakin tingginya laba yang mampu diperoleh, sehingga dapat mendorong semakin tingginya profitabilitas perusahaan. Begitu sebaliknya, apabila suatu perusahaan mengalami penurunan penjualan, maka laba perusahaan tersebut akan ikut turun dan mempengaruhi profitabilitas perusahan tersebut.

Hasil uji hipotesis kedua dalam penelitian ini ditemukan bahwa leverage berpengaruh negatif terhadap profitabilitas. Hal ini berarti jika leverage meningkat maka profitabilitas perusahaan akan menurun. Pengaruh yang signifikan menunjukkan bahwa leverage merupakan faktor utama yang mempengaruhi profitabilitas perusahaan. Hasil ini sesuai dengan pecking order theory yang menyatakan bahwa perusahaan yang menghasilkan laba yang tinggi, akan menggunakan hutang yang relatif sedikit karena perusahaan akan cenderung menggunakan dana internalnya

Hasil uji hipotesis ketiga dalam penelitian ini ditemukan bahwa Ukuran perusahaan tidak berpengaruh signifikan terhadap profitabilitas. Hal ini terjadi 
karena pasar kurang bereaksi terhadap banyaknya informasi yang tersedia pada perusahaan-perusahaan yang berskala besar dan pada saat pengumuman laba. Selain itu bisa saja perusahaan tidak memaksimalkan aset yang ada untuk mencapai keuntungan yang diinginkan. Sehingga dapat disimpulkan ukuran perusahaan tidak dapat dijadikan salah satu tolak ukur untuk menentukan kemampuan perusahaan menghasilkan laba. Karena perusahaan yang berukuran besar belum tentu mampu menghasilkan laba yang besar daripada perusahaan yang berukuran kecil. Hasil ini sesuai dengan hasil penelitian Fachrudin (2011) dan Febria (2013) yang menyatakan bahwa ukuran perusahaan bukan jaminan bahwa perusahaan memiliki kemampuan dalam menghasilkan profit yang baik. Pengaruh yang tidak signifikan ini diakibatkan oleh semakin besar ukuran suatu perusahaan, maka perusahaan tersebut akan membutuhkan biaya yang semakin besar untuk menjalankan aktivitas operasionalnya seperti biaya tenaga kerja, biaya administrasi dan umum serta biaya pemeliharaan gedung, mesin, kendaraan dan peralatan sehingga akan mampu mengurangi profitabilitas perusahaan.

Implikasi praktis dalam penelitian ini adalah bahwa manajemen dalam melakukan pengambilan keputusan sebaiknya memperhatikan informasi terkait pertumbuhan penjualan, dan leverage yang dimiliki oleh perusahaan, karena hal tersebut dapat mempengaruhi jumlah profitabilitas yang akan diperoleh perusahaan. Leverage adalah salah satu faktor penting yang memengaruhi profitabilitas karena leverage bisa digunakan perusahaan untuk meningkatkan modal perusahaan dalam rangka meningkatkan keuntungan. Penggunaan hutang dalam kegiatan pendanaan perusahaan tidak hanya memberikan dampak yang baik 
bagi perusahaan. Jika proporsi leverage tidak diperhatikan perusahaan hal tersebut akan menyebabkan turunnya profitabilitas karena penggunaan hutang menimbulkan beban bunga yang bersifat tetap. Selain leverage, pertumbuhan penjualan juga memiliki pengaruh yang strategis bagi perusahaan karena pertumbuhan penjualan ditandai dengan peningkatan market share yang akan berdampak pada peningkatan penjualan dari perusahaan sehingga akan meningkatkan profitabilitas dari perusahaan.

\section{SIMPULAN DAN SARAN}

Simpulan yang dapat diambil berdasarkan hasil penelitian dan pembahasan yang telah diuraikan pada bab sebelumnya yaitu pertama, pertumbuhan penjualan berpengaruh positif dan signifikan terhadap profitabilitas pada perusahaan Sektor Food and Beverage di BEI selama periode 2012-2016. Kedua, Leverage (Debt to Equity Ratio) berpengaruh negatif dan signifikan terhadap profitabilitas pada perusahaan Sektor Food and Beverage di BEI selama periode 2012-2016. Ketiga, ukuran perusahaan berpengaruh positif dan tidak signifikan terhadap profitabilitas pada perusahaan Sektor Food and Beverage di BEI selama periode 2012-2016.

Berdasarkan kesimpulan yang telah dikemukakan, maka peneliti dapat menyarankan bagi manajemen perusahaan, dalam pengambilan keputusan keuangan agar lebih mempertimbangkan pertumbuhan penjualan, dan leverage (DER) karena telah terbukti mempunyai pengaruh yang signifikan terhadap profitabilitas.

Saran yang dapat diberikan bagi peneliti selanjutnya yaitu lokasi penelitian terbatas hanya pada perusahaan food and beverage yang terdaftar di Bursa Efek 
Indonesia. Peneliti selanjutnya agar dapat dilakukan penelitian pada sektor perusahaan yang berbeda, seperti sektor pertambangan, sektor pertanian, sektor properti, sektor perdagangan, dan lain-lain. Penelitian selanjutnya juga diharapkan dapat mempertimbangkan penggunaan proksi lain untuk ukuran perusahaan seperti : jumlah karyawan, jumlah penjualan dan kapitalisasi pasar, dan melakukan penambahan variabel seperti perputaran persediaan, perputaran aset, usia perusahaan, rasio lancar dan variabel lainnya yang diduga dapat mempengaruhi profitabilitas. Karena nilai $\mathrm{R}^{2}$ penelitian ini sebesar $65,5 \%$ sehingga masih ada faktor-faktor lain yang mempengaruhi profitabilitas

\section{REFERENSI}

Ba-Abbad, Khaled and Nurwati Ashikkin Ahmad-Zaluki. 2012. The Determinants of Capital Structure of Qatari Listed Companies. International Journal of Academic Research in Accounting, Finance and Management Science, 2 (2), pp: 93-108.

Babalola, Yisau Abiodun. 2013. The Effect of Firm Size on Firms Profitability in Nigeria. Journal of Economics and Sustainable Development, 4 (5), pp: 9095.

Brigham, Eugene F. dan Joel F. Houston. 2010. Dasar-Dasar Manajemen Keuangan. Buku 2 edisi 11. Jakarta : Salemba Empat.

Dewi, Ni Kadek Venimas Citra., Cipta, Wayan., dan I Ketut Kirya. 2015. Pengaruh LDR, LAR, DER dan CR Terhadap ROA. e-Journal Bisma Universitas Pendidikan Ganesha, Vol 3(1), h: 1-10.

Fabozzi, J. Frank. 2000. Manajemen Investasi. Alih Bahasa: Tim Alih Bahasa Salemba Empat. Buku 2. Jakarta: Salemba Empat.

Fachrudin, Khaira Amalia. 2011. Analisis Pengaruh Struktur Modal, Ukuran Perusahaan, dan Agency Cost Terhadap Kinerja Perusahaan. Jurnal Akuntansi dan Keuangan, 13 (1), h: 37-46.

Farhana, Cintya Dewi., Gede Putu Agus Jana Susila., dan I Wayan Suwendra. Pengaruh Perputaran Persediaan dan Pertumbuhan Penjualan Terhadap Profitabilitas Pada PT. Ambara Madya Sejati Di Singaraja. E-Journal Bisma Universitas Pendidikan Ganesha Manajemen. 4, hh : 1-10. 
Febria, Ririind Lahmi. 2013. Pengaruh Leverage Dan Ukuran Perusahaan Terhadap Profitabilitas (Studi Empiris pada Perusahaan Property dan Real Estate yang Terdaftar di BEI). Jurnal Fakultas Ekonomi Universitas Negeri Padang, Hal : 1-18

Hansen, Verawati dan Juniarti. 2014. Pengaruh Family Control, Size, Sales Growth, dan Leverage Terhadap Profitabilitas Perusahaan Pada Sektor Perdagangan, Jasa, dan Investasi. Bussiness Accounting Review, 2 (1), h: 121-130.

Hastuti, Niken. 2010. Analisis Pengaruh Periode Perputaran Persediaan, Periode Perputaran Hutang Dagang, Rasio Lancar, Leverage, Pertumbuhan Penjualan dan Ukuran Perusahaan Terhadap Profitabilitas Perusahaan. Skripsi. Universitas Diponegoro, Semarang.

Jang, S. and Park, K. (2011). Inter-relationship Between Firm Growth and Profitability. International Journal of Hospitality Management, 30, pp: 1027-1035.

Jatismara, Raditya dan Pangestuti, Irene Rini Demi. 2012. Analisis Pengaruh TATO, DER, Dividend, Sales dan Current Ratio Terhadap Return on Asset (Studi pada Perusahaan Manufaktur yang Listed di Bursa Efek Indonesia Periode Tahun 2008-2010). Eprints Undip, Vol 3(1), h: 1-28.

Iqbal, Asif dan Wang Zhuquan. 2015. Working Capital Management and Profitability Evidence from Firms Listed on Karachi StockcExchange. International Journaloof Businessi and Management, 10 (2), pp: 231-235.

Kennedy, Nur Azlina dan Anisa Ratna Suzana. 2013. Faktor-Faktor yang Mempengaruhi Struktur Modal pada Perusahaan Real Estate and Property yang Go Public di Bursa Efek Indonesia. Jurnal Akuntasi, h:1-10.

Kusuma, H. 2005. Size Perusahaan dan Profitabilitas: Kajian Empiris Terhadap Perusahaan Manufaktur yang Terdaftar di Bursa Efek Jakarta. Jurnal Ekonomi Pembangunan, 1(1): 81-93.

Mahardika dan Marbun. 2016. Pengaruh Current Ratio Dan Debt To Equity Ratio Terhadap Return On Assets. Widyakala: 3(1), hal: 23-28.

Munawir, S. 2010. Analisa Laporan Keuangan. Edisi keempat, cetakan keempat belas. Yogyakarta: Liberty.

Nafarin,M. 2007. Penganggaran Perusahaan. Jakarta: Salemba Empat.

Nugroho, Elfianto. 2011. Analisis Pengaruh Likuiditas, Pertumbuhan Penjualan, Perputraran Modal Kerja, Ukuran Perusahaan dan Leverage Terhadap Profitabilitas Perusahaan. Skripsi. Universitas Diponegoro, Semarang.

Nurhasanah. 2012. Pengaruh Struktur Modal Terhadap Profitabilitas pada Perusahaan Manufaktur yang Terdaftar di Bursa Efek Indonesia (BEI). ILMIAH, 4 (3), h: 31-39. 
Nurmadi, Ruswan. 2013. Analisis Faktor-faktor yang Mempengaruhi Struktur Modal Perusahaan Manufaktur. Jurnal Keuangan dan Bisnis, 5 (2), h: 170178.

Pagano, P. and F. Schivardi. 2003. Firm Size Distribution and Growth. Scandinavian Journal of Economics, 105(2), pp: 255-274.

Purba, Ida Bagus Gde Indra Wedhana., dan Yadnya, Putu. 2015. Pengaruh Ukuran Perusahaan dan Leverage Terhadap Profitabilitas dan Pengungkapan Cororate Social Responbility. E-Jurnal Manajemen Unud, Vol 4(8), h: 2428-2443.

Putra, A.A. Wela Yulia., dan Ida Bagus Badjra. 2015. Pengaruh Leverage, Pertumbuhan Penjualan Dan Ukuran Perusahaan Terhadap Profitabilitas. EJurnal Manajemen Unud, Vol. 4, No. 7, Hal : 2052-2067

Ratnasari, Linda. 2016. Pengaruh Leverage, Likuiditas, Ukuran Perusahaan Terhadap Profitabilitas Pada Perusahaan Otomotif di BEI. Jurnal Ilmu dan Riset Manajemen. 1(6) hh : 1-15.

Riyanto, Bambang. 2011. Dasar-dasar Pembelanjaan Perusahaan. Edisi ke 4. Yogyakarta: Yayasan Penerbit Gajah Mada.

Rosyadah, Faizatur., Suhadak, dan Darminto. 2011. Pengaruh Struktur Modal Terhadap Profitabilitas (Studi Pada Perusahaan Real Estate and Property Yang Terdaftar di Bursa Efek Indonesia (BEI) Periode 2009 - 2011). Jurnal Administrasi Bisnis: 3(2): 1 - 11.

Santoso, Anita Carolina dan Juniarti. 2014. Pengaruh Family Control Terhadap Profitabilitas dan Nilai Perusahaan Sektor Aneka Industri. Bussiness Accounting Review. 2 (1), pp: 51-60.

Sari, Ni Made Vironika dan Budiasih, I.G.A.N. 2014. Pengaruh Debt to Equity Ratio, Firm Size, Inventory Turnover dan Assets Turnover pada Profitabilitas. E-Jurnal Akuntansi Universitas Udayana, 6 (2), h: 261-273.

Sartono, Agus. 2010. Manajemen Keuangan Teori dan Aplikasi. Yogyakarta:BPFE.

Sunarto dan Budi Agus Prasetyo,2009. Pengaruh Leverage, Ukuran dan Pertumbuhan Perusahaan terhadap Profitabulitas. Jurnal TEMA, 6(1), Hal 86- 103.

Suryaputra, Gladys dan Christiawan, Yulius Jogi. 2016. Pengaruh Manajemen Modal Kerja, Pertumbuhan Penjualan dan Ukuran Perusahaan Terhadap Profitabilitas Pada Perusahaan Properti dan Real Estate Yang Terdaftar di Bursa Efek Indonesia (BEI) Tahun 2010-2014. Business Accounting Review, Vol 4(1), h: 493-504 
Swastha, Basu dan T. Hani Handoko, 2001. Manajemen Pemasaran Analisis Perilaku Konsumen, Edisi 2, Liberty. Yogyakarta.

Syarib, Mochammad. 2016. Pengaruh Struktur Modal dan WTCO Terhadap Profitabilitas Perusahaan Semen di BEI. Jurnal Ilmu dan Riset Manajemen. Vol 5(12), hal: 1 - 16

Velnampy, T and Nimalathasan, B. 2010. Firm Size on Profitability: A Comparative Study of Bank of Ceylon and Commercial Bank of Ceylon Ltd in Srilanka. Global Journal of Management and Business Research, 10 (2), pp: 96-100.

Wahyuni, Sri. 2012. Efek Struktur Modal Terhadap Profitabilitas pasa Perusahaan Manufaktur yang Terdaftar di Bursa Efek Indonesia. Management Analysis 